\title{
Fluorescence Microscopic and Enzyme Histochemical Studies of the Innervation of the Human Spleen
}

\author{
Gyoetsu Kudoh, Kazuo Hoshi and Tadashige Murakami \\ Department of Surgery (Prof. T. Murakami), Tokyo Medical and Dental University \\ School of Medicine, Tokyo, Japan
}

Received October 26, 1978

Summary. The innervation of the human spleen was investigated by the fluorescence method for adrenergic nerve fibers (52 cases) and the enzyme histochemical method for cholinergic nerve fibers ( 27 cases). The spleens examined were removed by laparotomy chiefly for gastric cancer.

Adrenergic nerve fibers were demonstrated at the medioadventitial junction and the media in the trabecular arteries, whereas they occurred at the medioadventitial junction in the central and penicillar arteries. They were not found in the trabecular and pulp veins and venules, sheathed capillaries, avascular trabeculae, white and red pulp, and capsule. Nerves containing only a few adrenergic fibers and nerves without adrenergic fibers occurred close to the trabecular arteries. It was also demonstrated that nerves close to the trabecular arteries contain cholinergic fibers.

The present study first verifies histochemically that the human spleen is innervated doubly by adrenergic and cholinergic nerve fibers.

The distribution of the autonomic nervous system controlling the blood flow in the human spleen remains to be verified especially for the understanding of the pathogenesis of splenic disorders such as Banti's syndrome, hemolytic anemia and liver cirrhosis.

Extensive reviews by STöHR Jr. (1957) and Tischendorf (1969) are available on the innervation of the spleen of various animals including man. The previous studies were conducted mainly on the extrasplenic nerves and there have been very few studies on the determination of the sympathetic and parasympathetic nerve fibers. The distribution of the nerves within the human spleen was examined by HARTING (1952) with the silver staining method, but distinction between sympathetic and parasympathetic nerves in animals and man was not attempted. Recently studies on the distribution of the splenic nerves have been performed by modern methods using several animals and man. Adrenergic nerve fibers were identified by the fluorescence method of FALCK and HILlARP (1962), whereas cholinergic nerve fibers, by the enzyme histochemical method of KARnovsky and RooTs (1964). Occurrence of adrenergic nerve fibers within the surgically removed human spleen was verified only by Heusermann and Stutte (1977) by electron microscopy. However, the distribution of cholinergic nerve fibers within the spleen of various animals 
and man has not been demonstrated as far as the authors are aware.

In the present study, the fluorescence method and the enzyme histochemical method were used to examine in detail the distribution of adrenergic nerve fibers and cholinergic nerve fibers within the human spleen. The results form the basis of this report.

\section{MATERIALS AND METHODS}

Human spleens were studied by the fluorescence method ( 52 cases) and by the enzyme histochemical method (27 cases). The primary diseases of the patients are shown in Table 1. Many spleens examined in the present study were removed to extirpate splenic hilar lymph nodes in radical surgery for gastric cancer.

\section{Fluorescence method}

In 52 spleens (Table 1) the fluorescence histochemical method of FALCK and HillaRP (1962) was applied for localization of adrenergic nerve fibers. Tissue blocks, measuring $10 \times 10 \times 10 \mathrm{~mm}$, were quickly frozen in acetone-dry ice and freeze-dried at $-40^{\circ} \mathrm{C}$ and $5 \times 10^{-4} \mathrm{mmHg}$ for $2-5$ days. After the specimens were put in a desiccator within a warm bath at $37^{\circ} \mathrm{C}$ for $3 \mathrm{hrs}$, they were exposed to paraformaldehyde fumes in a desiccator at $80^{\circ} \mathrm{C}$ for $1 \mathrm{hr}$ and embedded in paraffin. Sections, $4-10 \mu$ thick, were deparaffined in xylene, mounted on slides in Entellan (Merck) and examined using a fluorescence microscope equipped with an Osrum HBO-200 mercury light source, BG-12 excitation filter, and a barrier filter which excluded light below $500 \mathrm{~nm}$. Distribution of yellow-green fluorescence was recorded by Kodak High Speed Ektachrome (EHB) films, ASA 125 . The sodium borohydride technique of ConRoDI, Hillarp and Jonsson (1964) was utilized to identify catecholamine-specific fluores-

Table 1. Clinicopathological data of the spleens and histochemical methods applied

\begin{tabular}{lrc}
\hline \multicolumn{1}{c}{ Disease } & \multicolumn{2}{c}{ No. of patients } \\
& A & B, C \\
\hline Esophageal cancer & 1 & 1 \\
Gastric cancer (early cancer) & 5 & 2 \\
Gastric cancer (advanced cancer) & 38 & 21 \\
Gastric sarcoma & 2 & \\
Gastric ulcer & 1 & \\
Duodenal ulcer & 1 & 1 \\
Zollinger-Ellison syndrome & 1 & \\
Pancreatic cancer & 2 & 2 \\
Cancer of descending colon & 1 & \\
\multicolumn{1}{c}{ Total } & 52 & 27 \\
\hline
\end{tabular}

A: fluorescence method of FALCK and HILLARP

B: enzyme histochemical method of KARNovsky and Roots

C: modified fluorescence method of EL-BADAWI and ScHENK 
cence: Autofluorescence in all regions of the spleen was resistant to the reduction, whereas the catecholamine fluorescence was reduced by the technique and recovered by reexposing the reduced tissue sections to paraformaldehyde. After fluorescence microscopy, Entellan was removed by xylene and the same sections were stained by hematoxylin-eosin to confirm the location of adrenergic nerve fibers.

\section{Enzyme histochemical method}

Distribution of true cholinesterase (ChE) or acetylcholinesterase (AChE) was detected using the enzyme histochemical method of Karnovsky and Roots (1964). This examination was performed in 27 spleens (Table 1 ). Tissue blocks, measuring $10 \times 10$ $\times 10 \mathrm{~mm}$, were frozen in acetone-dry ice and cut into $10 \mu$ using a Lipshaw cryostat at $-25^{\circ} \mathrm{C}$. The sections were mounted on slides, rapidly dried and then incubated at $37^{\circ} \mathrm{C}$ for 1, 2, 4 and $8 \mathrm{hrs}$ with and without the substrate acetylthiocholine iodide (Sigma Chemical Company) or butyrylthiocholine iodide (Sigma Chemical Company). In some incubations, iso-octametylpyrophosphate (Sigma Chemical Company) was used to inhibit pseudo-ChE. After incubation, the sections were mounted in Entellan, and examined by light microscopy to detect the reddish-brown precipitate of copper ferrocyanide (Hatchett's Brown) indicating the sites of AChE. Adjacent sections were stained by hematoxylin-eosin to facilitate the localization of the enzyme. For the comparison of the distribution of adrenergic nerve fibers and AChEcontaining nerve fibers, modified fluorescence and AChE methods introduced by EL-BADAWI and SchENK (1967) were also applied.

\section{RESULTS}

\section{Distribution of adrenergic nerve fibers}

Adrenergic nerve fibers were demonstrated mainly at the medioadventitial junction and partly within the media in the trabecular arteries. In the central and penicillar arteries they were concentrated to the medioadventitial junction (Fig. 1-3).

In the remaining vasculature within the spleen, i.e., the trabecular and pulp veins, and the sheathed capillaries no fluorescent structures were found. As it is known that the splenic nerves enter the spleen along the splenic arteries, the splenic capsule was expected to contain noradrenaline fluorescence. However, the fluorescence there could not be distinguished from autofluorescence produced by rich collagenous fibers. Adrenergic nerve fibers were not demonstrated in the parts of white and red pulp devoid of blood vessels. These findings were confirmed in 291 blocks taken from 52 spleens. Occurrence of nerves close to the trabecular arteries was demonstrated in 79 of the 291 blocks, and in 15 of the 79 blocks they were found to contain adrenergic fibers (Fig. 4, 5); in 64 of the 79 blocks no adrenergic fibers could be found in the nerves (Fig. 6, 7).

\section{Distribution of cholinergic nerve fibers}

The enzyme histochemical method was utilized to examine the presence of true $\mathrm{ChE}$ or AChE. The deep reddish-brown precipitate of copper ferrocyanide, indicating a high activity of AChE was not seen after incubation of sections for 1-2 hrs, but it was clearly demonstrated after $8 \mathrm{hr}$ incubation. The effect of the inhibitor of 


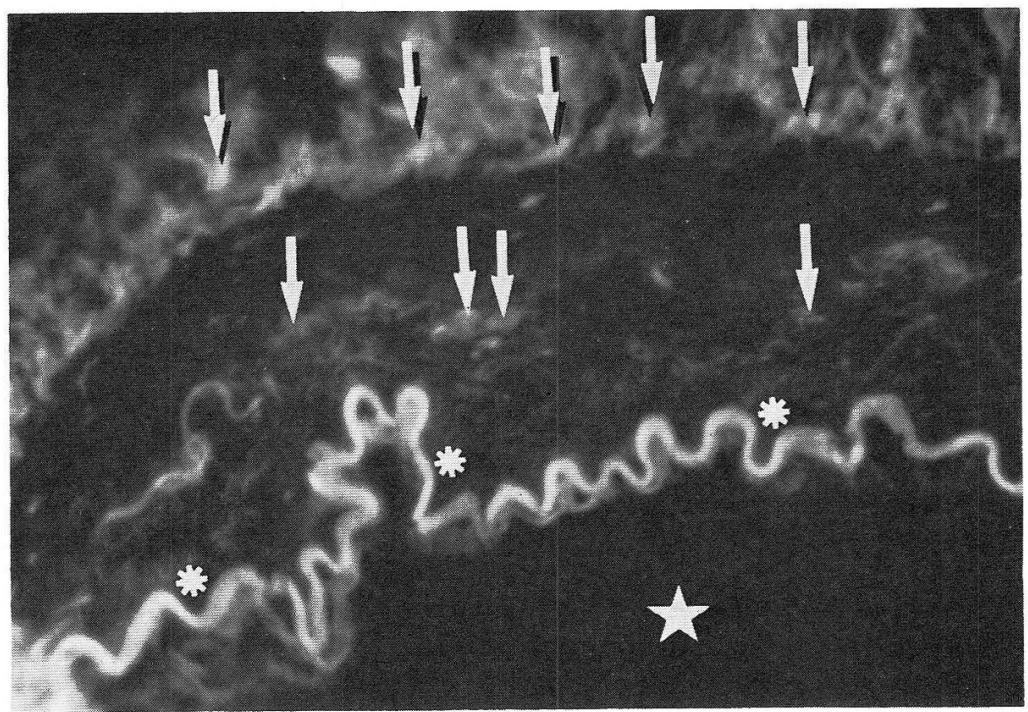

Fig. 1. Fluorescing adrenergic fibers in and near a trabecular artery of the human spleen. Note that the adrenergic fibers are concentrated at the medioadventitial junction and the media of the artery (arrows). Autofluorescence of the internal elastic lamina is indicated by asterisks, lumen of the vessel by 2 . Falck-Hillarp method. $\times 100$
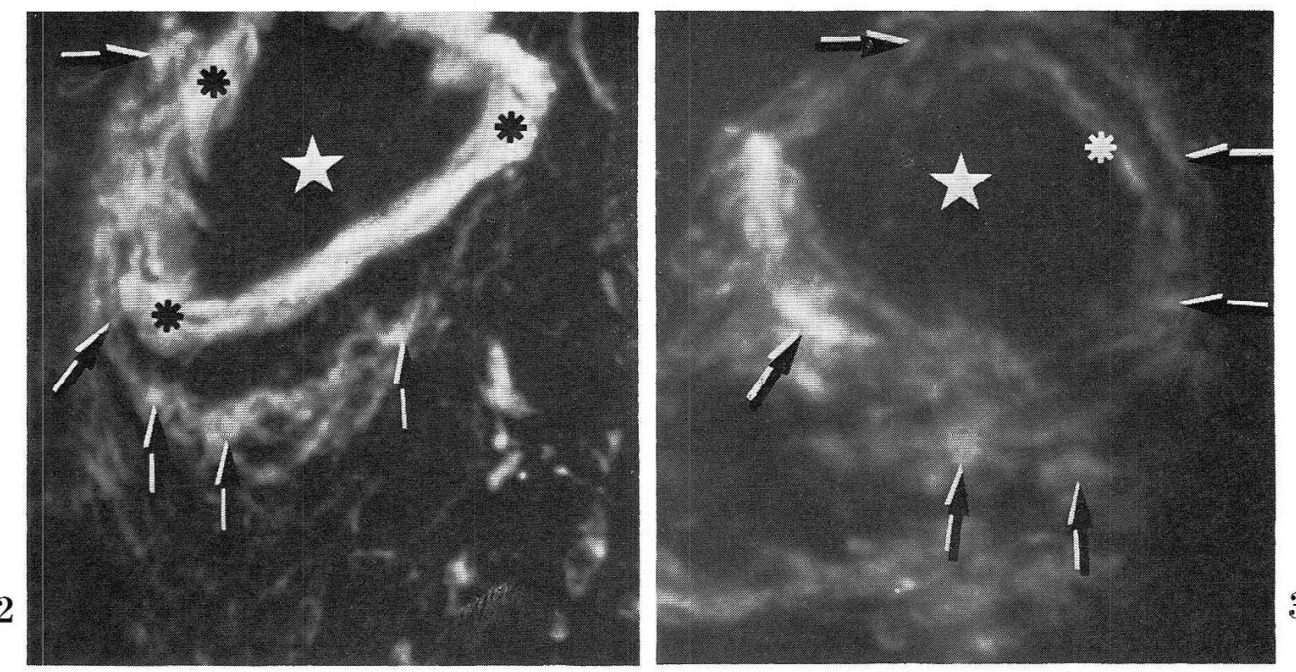

Fig. 2. and 3. Fluorescing adrenergic fibers in and near a central artery (Fig. 2) and a penicillar artery (Fig. 3) of the human spleen. Note that the adrenergic fibers are concentrated at the medioadventitial junction of the artery (arrows). Autofluorescence of the internal elastic lamina is indicated by asterisks, lumen of the vessel by $i s$. Falck-Hillarp method. Fig. 2: $\times 200$; Fig. $3: \times 400$ 


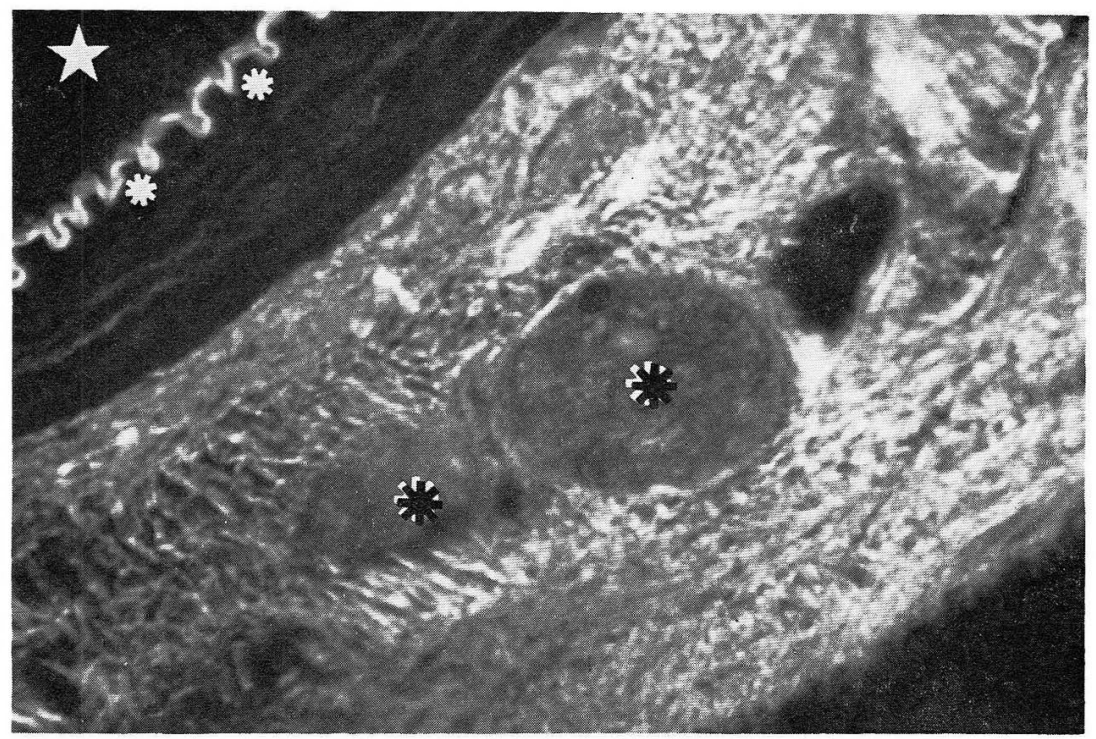

Fig. 4. Showing a cross or oblique section of two nerve bundles containing fluorescing adrenergic fibers (large asterisks). Autofluorescence of the internal elastic lamina is indicated by small asterisks, lumen of the vessel by is. FALCK-Hill ARP method. $\times 100$

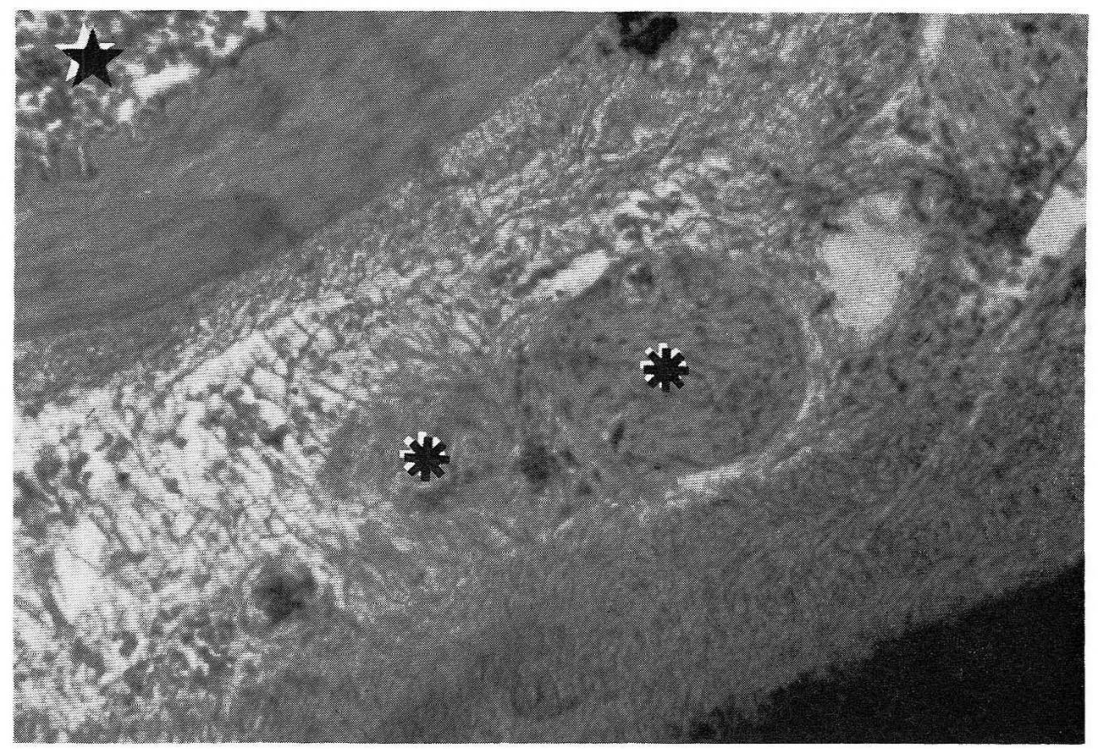

Fig. 5. Same section as Figure 4. After the fluorescence microscopy, the same section was subjected to hematoxylin-eosin staining. $i \frac{5}{2}$ Lumen of the trabecular artery. $\times 100$ 
pseudo-ChE was confirmed to be constant for more than 8 hrs by comparison of the preparations for the total $\mathrm{ChE}$ (true $\mathrm{ChE}+$ pseudo-ChE) and pseudo-ChE as well as the controls incubated for the same length of time. By this method, the deep reddish-brown precipitate was shown only within the nerves close to the trabecular arteries. High activity of $\mathrm{AChE}$ as also demonstrated in the erythrocytes within the

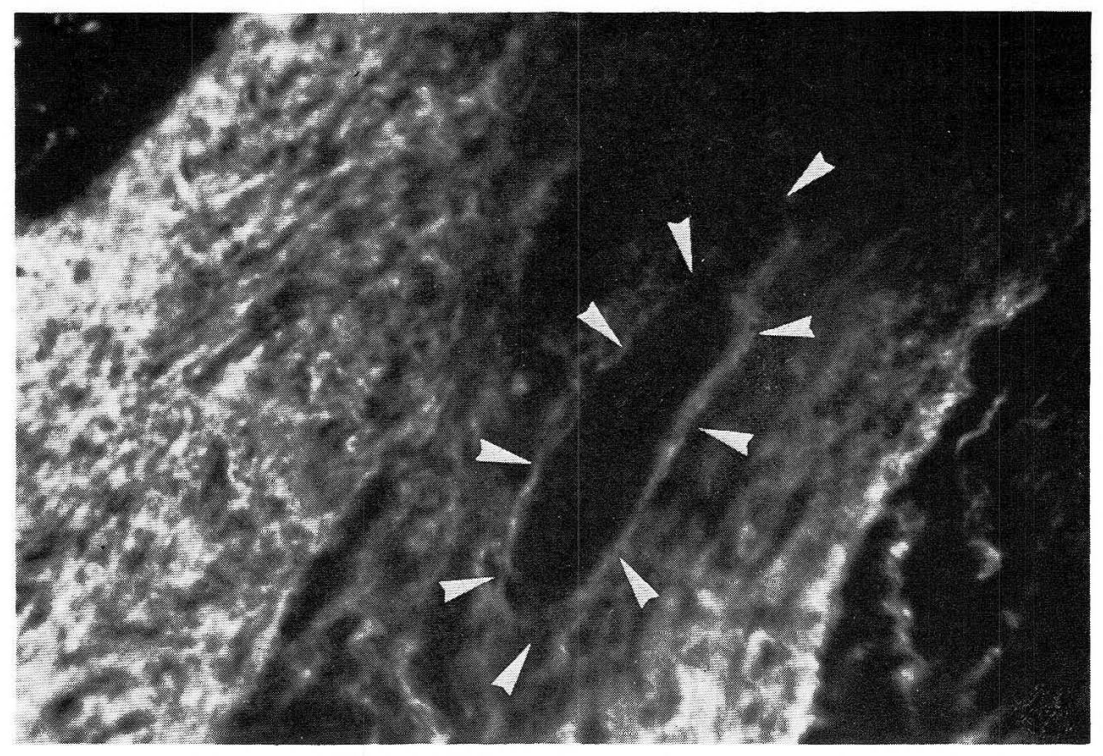

Fig. 6. No adrenergic fibers are seen in the nerve bundle (arrow heads) near the trabecular artery. Falck-Hillarp method. $\times 100$

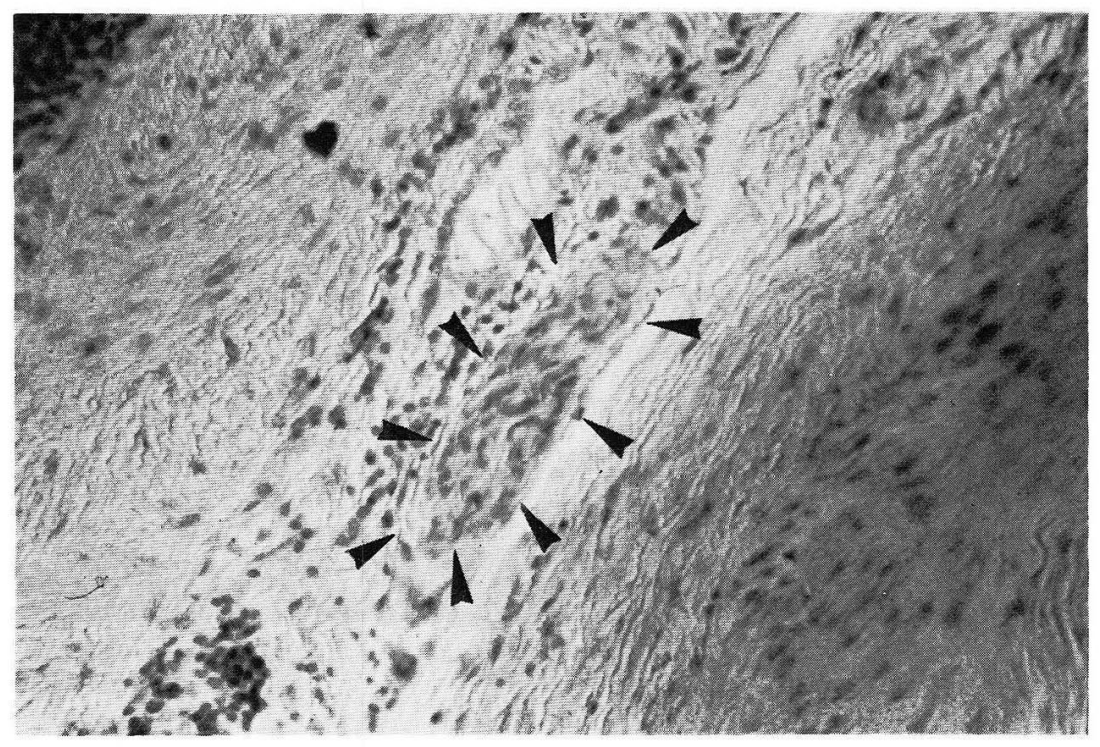

Fig. 7. Same section as Figure 6. Hematoxylin-eosin stain. $\times 100$ 
trabecular arteries and in the germinal centers of the white pulps, whereas moderate activity of AChE as found in the marginal zones of the spleen (Fig. 8). No activity of $\mathrm{AChE}$ was shown in any other sites except erythrocytes within the vessels.

By comparing adjacent sections alternately treated by the histochemical method of KARNOVSKY and RoOTs (1964) and with hematoxylin-eosin, it was found that only nerves $40-50 \mu$ thick and close to the trabecular arteries $250-300 \mu$ in thickness were demonstrated to be enzyme positive. Distribution of adrenergic fibers within the nerves in adjacent sections was examined by the modificd fluorescence method of FAlck andHillarp (El-Badawi and Schenk, 1967). The cholinergic fibers could be demonstrated in 34 of 116 blocks examined within the nerves close to the trabecular arteries, whereas no adrenergic fibers were demonstrated in those nerve bundles (Fig. 9-11).

\section{DISCUSSION}

STÖHR Jr. (1957) described that the splenic nerves come from the ganglion coeliacum, but vagal nerves also contribute fibers to them. However, Tischendorf (1969) did not report the presence of parasympathetic components of the splenic nerve. Both authors agreed that the spleen is mainly innervated by sympathetic nerve fibers. Mammalian spleens have recently been subjected to the fluorescence method of FAlCK and Hillarp (1962), the enzyme histochemical method of Karnovsky and Roots (1964) and electron microscopy. Fluorescence microscopic studies on the splenic innervation have been carried out in the dog (DAHLström and ZeTterström,

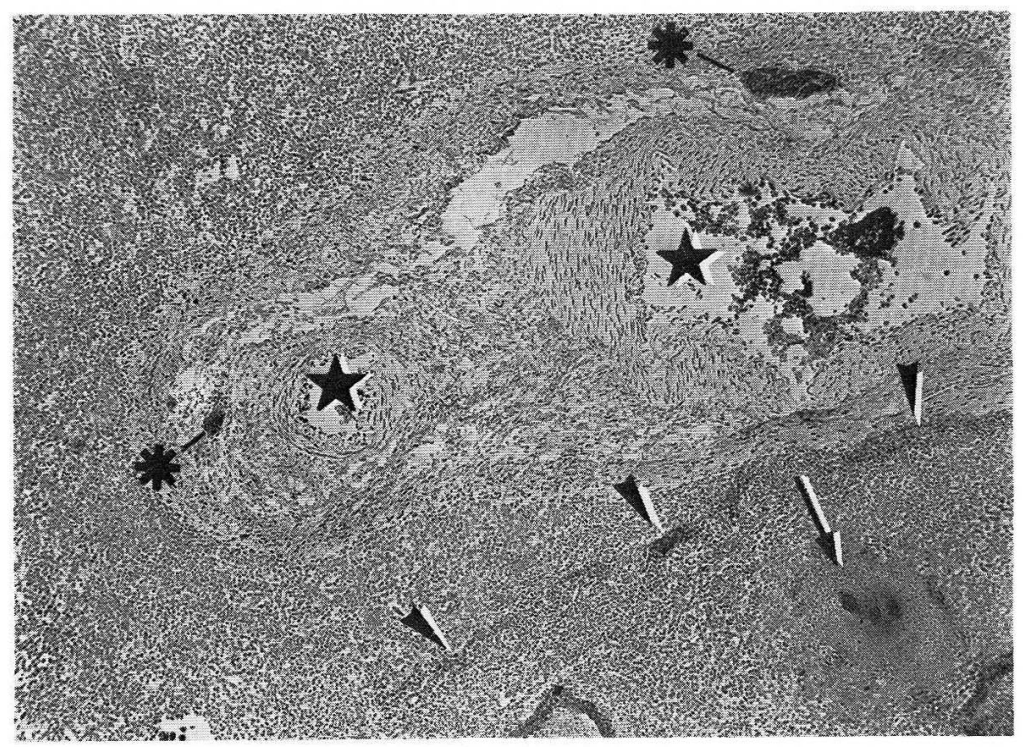

Fig. 8. Showing acetylcholinesterase-positive nerve bundles (asterisks) along the trabecular artery $(\star)$. A germinal center in the white pulp is indicated by an arrow. Arrow heads show the marginal zone of the white pulp. Karnovsky-Roots method. $\times 150$ 


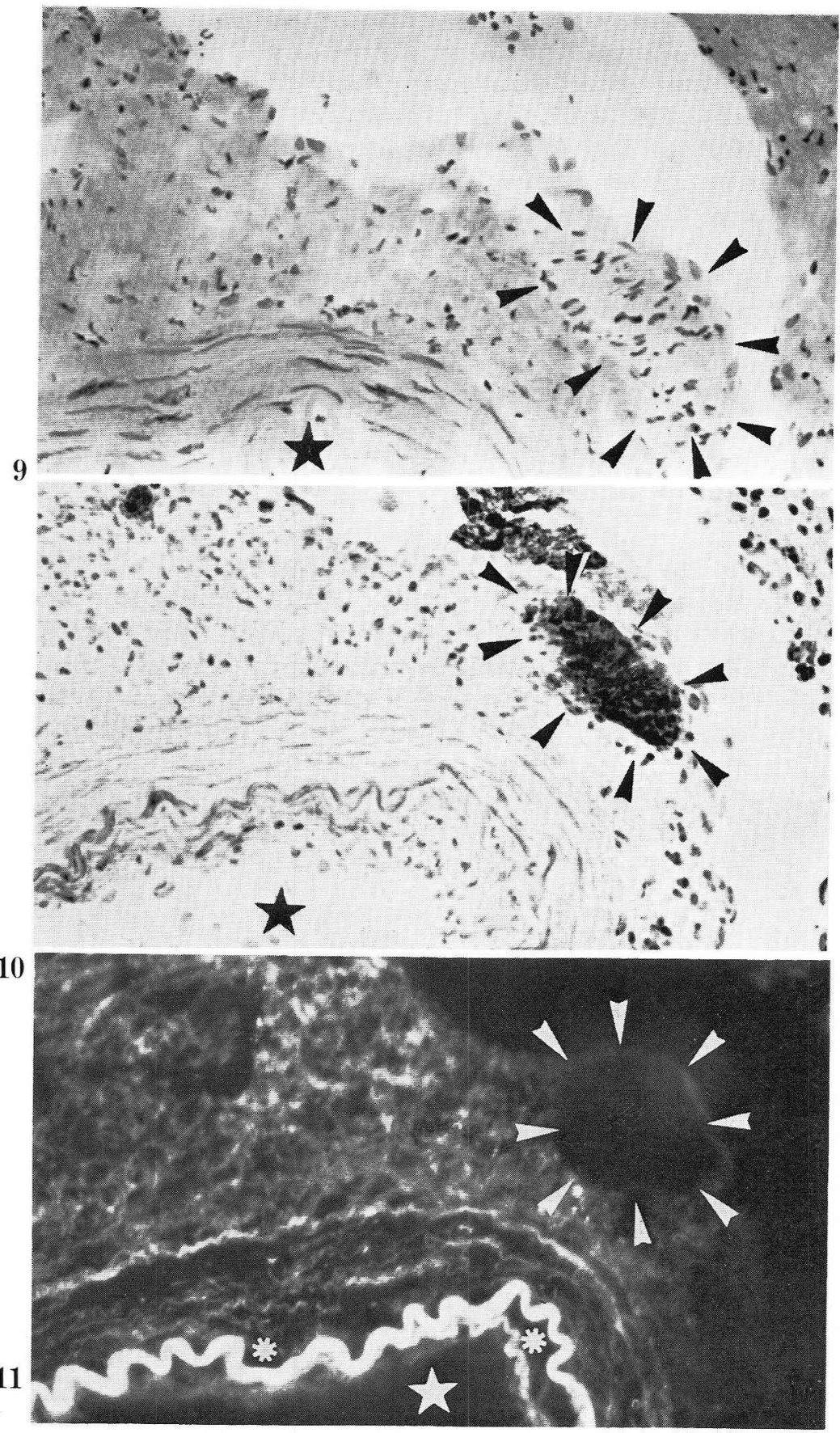

Fig. 9-11. Legends on opposite page. 
1965; Zetterström et al., 1973), cat (Gillespie and Kirpekar, 1966; FillenZ, 1970), mouse (Reilly, McCuskey and Meineke, 1976) and rat (Fujiwara and TANaka, 1966). In these animals adrenergic nerve fibers were found at the medioadventitial junction of arteries and arterioles of the hilum, trabeculae and red and white pulps. Veins, venules, the channels in the red pulp, trabeculae and the splenic capsule were found to have no adrenergic nerve fibers. In contrast to the mouse, the smooth muscle of avascular trabeculae and splenic capsule of the dog (DAHLSTRöm and ZETTERSTRöm, 1965; Zetterström et al., 1973), cat (Gillespie and KirPekar, 1966; FillenZ, 1970) and rat (FUJIWARA and TANAKA, 1966) were found to have adrenergic nerve fibers. Enzyme histochemical studies on the splenic innervation were carried out in the cat (Fillenz, 1970) and mouse (Reilly, McCuskey and Meineke, 1976). Fillenz (1970) indicated that the AChE present in the cat spleen was confined to non-nervous structures and the extrasplenic portion of the splenic artery. However, the network of AChE-containing fibers was lost as soon as the splenic artery entered the spleen. Reilly, McCuskey and Meineke (1967) also reported that cholinergic nerve fibers within the mouse spleen were not found with the modified enzyme histochemical method of Karnovsky and Roots (EL-BADAwi and Schenk, 1967). Electron microscopic studies on the splenic innervation were carried out in the dog (ZETTERSTRÖM et al., 1973), cat (Zwillenberg and Zwillenberg, 1963; Tranzer and Thoenen, 1967; Fillenz, 1970), rabbit (Moore, Mumaw and Schoenberg, 1964; Olah, Röhlich and Törö, 1975), mouse (Galindo and Imaeda, 1962) and man (Heusermann and Stutte, 1977). ZETTERSTRÖM et al. (1973) reported the presence of adrenergic nerve fibers in the red pulp of the dog spleen and a possible relationship between adrenergic nerve terminals and blood elements. ZwILlenberG and ZwILlEnberG (1963) detected the presence of Schwann cells and unmyelinated axons among the surrounding cells in the sheathed capillaries of the cat spleen. Some of the axons were said to be closely related to the endothelial cells, which were picked with fine filaments, about $8 \mathrm{~m} \mu$ in diameter. Tranzer and Thoenen (1967) reported the importance of the agranular vesicles with a diameter of $450 \AA$ in the cat spleen. They showed that such vesicles developed from the granular vesicles owing to the loss of noradrenaline during fixation and that they did not constitute a separate type of vesicle comparable to those in cholinergic axon terminals. FILLENZ (1970) demonstrated the ultrastructural findings on terminal axons in the cat spleen and was able to distinguish four different types of axon with respect to their spatial relationship with smooth muscle cells. Moore, Mumaw and Schoenberg (1964) observed unmyelinated nerve fibers throughout the white and red pulp of the spleen. Some of the fibers were said to be closely associated with small blood vessels that resembled sheathed capillaries. Unfortunately, these findings were not illustrated. OLAH, RöHLich and Törö (1975) demon-

Fig. 9. A nerve bundle (arrow heads) is located close to the trabecular artery ( $\star$ ) in the human spleen. Hematoxylin-eosin stain. $\times 100$

Fig. 10. An adjacent section to Figure 9. Intense acetylcholinesterase activity is demonstrated in the nerve bundle (arrow heads). No acetylcholinesterase activity is seen in the wall of the trabecular artery $(\star)$. KARNovsKy-Roots method. $\times 100$

Fig. 11. Adjacent section to Figure 9 and 10. Arrow heads indicate a nerve bundle close to the trabecular artery $(\hat{\xi})$. No adrenergic fibers are contained in the nerve bundle. Autofluorescence in the internal elastic lamina is indicated by asterisks. EL-BADAwi-Schenk method. $\times 100$ 
strated that very fine unmyelinated nerve fibers were found at the periphery, i.e., in association with the terminal capillaries of the rabbit spleen. The axons were surrounded by the cytoplasmic processes of reticulum cells accompanying the vessels and were in contact with the basal cytoplasmic processes of endothelial cells. GALINDO and IMAEDA (1962) described the rare occurrence of unmyelinated nerve fibers in the white pulp of the mouse spleen. Heusermann and Stutte (1977) examined the innervation in four normal human spleens. They reported that unmyelinated nerve fibers accompanied the arterial vascular system up to the arterioles of the red pulp. At the medioadventitial junction the nerve fibers terminated against the smooth muscle cells of the blood vessels in a manner which is typical of the autonomic nervous system. The terminal axons contained small and large granular vesicles and thus were considered to be adrenergic nerve fibers. In contrast to the results of an earlier study made by HARTING (1952) using the silver impregnation method, these authors could not demonstrate nerves in the red and white pulp. They suggested that the capsule and trabeculae contained a variable number of adrenergic nerves, depending on the number of smooth muscle cells.

Hitherto no fluorescence and enzyme histochemical studies of nerves in the human spleen have been available, due to the difficulty in obtaining fresh human spleens which are required for both methods.

The present paper is the first report of the application of fluorescence microscopy for adrenergic nerve fibers to the normal human spleen. Adrenergic nerve fibers to the trabecular, central and penicillar artery of the human spleen were demonstrated at the medioadventitial junction. This agrees with the electron microscopic findings in human spleens obtained by Heusermann and Stutte (1977). Our observations that adrenergic fibers occurred in the media of the trabecular artery and that they were not found in the splenic capsule do not agree with the findings by Heusermann and Stutte (1977).

It seems a common finding in man and some animals that the adrenergic nerve fibers within the spleen exist in the trabeculae and at the medioadventitial junction of the walls of arteries and arterioles.

In the present study, the enzyme histochemical results on the cholinergic nerves in the normal human spleen are also reported for the first time. It was thus revealed that cholinergic nerve fibers occur close to the arteries within the trabeculae of the human spleen. They are presumed to be the parasympathetic postganglionic fibers judging from the intrasplenic nature of their location. Occurrence of cholinergic nerve fibers within the spleen in various animals except man has not been demonstrated histochemically.

Acknowledgement. The authors are indebted to Prof. Kenjiro Wake (Department of Anatomy) for his help in discussing the paper. Acknowledgement is also extended to Dr. Kiyoshi SAItoH (Department of Pathology) for technical assistance. 


\title{
ヒト脾臓の神経支配の螢光組織化学的および酵素組織化学的研究
}

\author{
工藤驍悦，星 和夫，村上忠重
}

この研究では おむに胃癌の開腹手術中に摘出された脾臟を用いて。ヒト脾臓の神経支配を 検索した．すなわち 螢光組織化学的方法 (52症例)，酵素組織化学的方法 (27症例) を用 いて，それぞれ アドレナリン作動性神経線維、コリン作動性神経線維を検索した。

ヒト脾臟内のアドレナリン作動性神経線維は，脾柱動脈の外膜と中膜の境界および中膜 飞, 中心動脈，筆毛動脈の外膜と中膜の境界飞まで認められたが。脾柱および赤脾䯣の静 脈と細静脈，莢毛細管，血管を含まない脾柱。白脾䯣，赤脾䯣および脾被膜には認められ なかった，脾柱内の脾柱動脈の周囲に、アドレナリン作動性神経線維を少し含えでいる神 経と 全く含えでいない神経の存在を認めた。また脾柱内の脾柱動脈の周囲にっコリン作動 性神経線維の存在を認めた。

以上の結果,ヒト脾臟はアドレナリン作動性神経線維预よび コリン作動性神経線維の両 方の支配をらけていることが 組織化学的に初めて明らかにされた。

\section{REFERENCES}

Corrodi, H., N.-A. Hillarp and G. Jonsson: Fluorescence methods for the histochemical demonstration of monoamines. 3. Sodium borohydride reduction of the fluorescent compounds as a specificity test. J. Histochem. Cytochem. 12: 582-586 (1964).

Dahlström, A. B. and B. E. M. Zetterström: Noradrenaline stores in nerve terminals of the spleen: changes during hemorrhagic shock. Science 147: 1583-1585 (1965).

El-Badawi, A. and E. A. Schenk: Histochemical methods for separate, consecutive and simultaneous demonstration of acetylcholinesterase and norepinephrine in cryostat sections. J. Histochem. Cytochem. 15: 580-588 (1967).

Falck, B : Observations on the possibilities of the cellular localization of monoamines by a fluorescence method. Acta physiol. scand. 56 (Suppl. 197): 1-26 (1962).

Falck, B., N.-Å. Hillarp, G. Thieme and A. Torp: Fluorescence of catecholamines and related compounds condensed with formaldehyde. J. Histochem. Cytochem. 10: 348-354 (1962).

Fillenz, M.: The innervation of the cat spleen. Proc. Roy. Soc. Lond. B. 174: 459-468 (1970).

Fujiwara, M. and C. Tanaka: The distribution of monoamines in the rat spleen. (In Japanese). Fol. pharmacol. jap. 62: 198 (1966).

Galindo, B. and T. Imaeda : Electron microscope study of the white pulp of the mouse spleen. Anat. Rec. 143: 399-415 (1962).

Gillespie, J. S. and S. M. Kirpekar : The histological localization of noradrenaline in the cat spleen. J. Physiol. 187: 67-79 (1966).

Harting, K.: Vergleichende Untersuchungen über die mikroskopische Innervation der Milz des Menschen und einiger Säugetiere. Ergebn. Anat. Entw.-Gesch. 34: 1-60 (1952).

Heusermann, U. and H. J. Stutte: Electron microscopic studies of the innervation of the human spleen. Cell Tiss. Res. 184: 225-236 (1977).

Karnovsky, M. J. and L. Roots : A direct-coloring thiocholine method for cholinesterases. J. Histochem. Cytochem. 12: 219-221 (1964). 
Kirpekar, S. M., A. R. Wakade and J. C. Prat: Histochemical demonstration for the release of norepinephrine from the sympathetic nerves in the cat spleen. Experientia 28: 36-37 (1972).

Moore, R. D., V. R. Mumaw and M. C. Schoenberg: The structure of the spleen and its functional implications. Exp. mol. Pathol. 3: 31-50 (1964).

Olah, I., R. Röhlich and I. Törö : Ultrastructure of lymphoid organs. An electron-microscopic atlas. Paris, Masson, 1975.

Reilly, F. D., R. S. McCuskey and H. A. Meineke: Studies of the hemopoietic microenvironment. VIII. Adrenergic and cholinergic innervation of the murine spleen. Anat. Rec. 185: 109-118 (1976).

Stöhr, Ph., Jr.: Mikroskopische Anatomie des vegetativen Nervensystems. In: (ed. by) W. Bargmann: Möllendorffs Handbuch der mikroskopischen Anatomie des Menschen. IV/5. Springer Verlag, Berlin-Göttingen-Heidelberg, 1957.

Tischendorf, F.: Die Milz. In: (ed. by) W. Bargmann: Möllendorffs Handbuch der mikroskopischen Anatomie des Menschen. VI/6. Springer Verlag, Berlin-Heidelberg-New York, 1969.

Tranzer, J.P. and H. Thoenen : Elektronenmikroskopische Untersuchungen am peripheren sympathischen Nervensystem der Katze: physiologische und pharmakologische Aspekte. NaunynSchmiedebergs Arch. Pharmakol. exp. Pathol. 257: 73-75 (1967).

Zetterström, B. E. M., T. Hökfelt, K.-A. Norberg and P. Olsson : Possibilities of a direct adrenergic influence on blood elements in the dog spleen. Acta chir. scand. 139: 117-122 (1973).

Zwillenberg, L. O. and H. H. L. Zwillenberg : Zur Struktur und Funktion der Hülsencapillaren in der Milz. Z. Zellforsch. 59: 908-921 (1963).

工藤 驍 悦

113 東京都文京区湯島 1-5-45

東京医科歯科大学

第一外科学教室
Dr. Gyoetsu KudoH

The first Department of Surgery

Tokyo Medical and Dental University

School of Medicine

No. 5-45, Yushima 1-Chome, Bunkyo-ku

Tokyo, 113 Japan 